\title{
HCV genotype-specific correlation with serum markers: Higher predictability for genotype $4 a$
}

Waqar Ahmad', Bushra ljaz ${ }^{1}$ Fouzia T Javed ${ }^{2}$, Humera Kausar', Muhammad T Sarwar', Sana Gull', Sultan Asad', Imran Shahid ${ }^{1}$ and Sajida Hassan ${ }^{1^{*}}$

\begin{abstract}
Background: Several factors have been proposed to assess the clinical outcome of HCV infection. The correlation of HCV genotypes to possible serum markers in clinical prediction is still controversial. The main objective of this study was to determine the existence of any correlation between HCV genotypes to viral load and different clinical serum markers.

Methods: We performed a prospective cross-sectional and observational study. About 3160 serum HCV RNA positive patients were chosen from 4020 randomly selected anti-HCV positive patients. Statistical analysis was performed using the SPSS 16 software package. ROC (receiver operating characteristics) curves were used to compare diagnostic values of serum markers to predict genotypes.
\end{abstract}

Results: The most prevalent genotype was 3a (73.9\%) followed by $1 \mathrm{a}(10.7 \%), 4 a(6.4 \%)$ and 3b (6.1\%) in Pakistani population. No correlation was found between viral load and serum markers for genotype 3a in a large no. of sample $(n=2336)$. While significant correlation was observed between viral load and AST in genotype $3 b$, ALP with viral load and ALT for genotype 1a. Patients with genotype 4a showed a significant inverse correlation with viral load and Hb level and AST with ALP. For genotype 4a, AUC (area under the curve) of ALT, ALP, AST, bilirubin, $\mathrm{Hb}$ level and viral load was $0.790,0.763,0.454,0.664,0.458$ and 0.872 respectively.

Conclusions: In conclusion, there was a significant variable response of HCV genotypes with serum markers. Severity of disease is independent of serum marker level in genotype 3a, while the liver damage in genotype $4 a$ may associate with viral cytopathic effect as well as the immune-mediated process. An index using six serum markers may correctly predict genotype $4 a$ in patients with $\geq 75 \%$ accuracy.

\section{Introduction}

Hepatitis $\mathrm{C}$ virus (HCV) is a major cause of liver associated diseases all over the world. An estimated $3 \%$ of the world's populations (more than 350 million people) are chronically infected with $\mathrm{HCV}$, which is the main cause of liver fibrosis, cirrhosis and hepatocellular carcinoma $(\mathrm{HCC})$ in a substantial number of patients $[1,2]$. Due to considerable sequence diversity and sequence comparisons in different parts of hepatitis $\mathrm{C}$ virus genome, classification of the virus into a series of genotypes showed distinct geographical and frequency distribution across the whole world [3-6].

\footnotetext{
* Correspondence: sajihassan2004@yahoo.com

'Applied and Functional Genomics Lab, Centre of Excellence in Molecular Biology, University of the Punjab, Lahore-53700, Pakistan Full list of author information is available at the end of the article
}

Approximately, 10 million people in Pakistan are infected with $\mathrm{HCV}$ [7]. It is well established factor that in patients infected with HCV, the clinical findings, genotypes and viral load are strong predictors for the outcome of antiviral therapy [8,9]. The most prevalent genotype in Pakistan is $3 \mathrm{a}$ followed by $3 \mathrm{~b}$ and $1 \mathrm{a}$ [10]. Due to high prevalence of genotype $3 \mathrm{a}$ in Pakistan; HCV genotyping is not recommended for HCV infected patients routinely by Pakistan's Society of Gastroenterology [11]. Secondly, due to poverty and cost of genotyping test, many patients refused to do genotyping. Nevertheless, genotyping is important because it not only provides information as to strain variation and potential association with disease severity but also related to the possibility of treatment response, as the treatment plan of chronic $\mathrm{HCV}$ infection with interferon varies with the genotype being treated $[12,13]$. It is reported that treatment with interferon is
Ciomed Central 
more effective in patients with genotypes 2 and 3 than in patients infected with genotypes 1 and $4[14,15]$. Several studies revealed that HCC develops in 1-4\% of patients and liver biopsy is considered the gold standard to identify liver fibrosis. Unfortunately, procedure of liver biopsy is invasive, expensive and unsuitable for all patients with severe side effects leading to death $[1,11,15,16]$. An assessment of the disease development based on clinical findings is still critical for patients infected with $\mathrm{HCV}$. At present, the clinicopathological significance of serum biochemical markers and viral load and their relationship among different genotypes is not well known. Several authors tried to find accurate noninvasive markers of liver damage and developed correlations between the serum hyaluronic acid levels, collagen level, platelet count, serum bilirubin levels, HCV viral load, genotypes and elevated ALT/AST levels in HCV infected patients, but no clear conclusions were formed [17-23].

In present study, we investigated the correlation of several clinical findings like $\mathrm{Hb}$ level, bilirubin level, ALT, ALP and AST and viral load in patients with different genotypes. The ideal serum markers for genotype determination should have good sensitivity, be readily available, inexpensive, reproducible, safe and able to predict genotypes with accuracy. The need of genotyping may be eradicated if the serum biochemical markers with high positive or negative predictive values of several genotypes can be obtained and thus minimize the cost of genotyping and liver biopsy.

\section{Materials and methods Patients}

Patients of this study were the people referred to Pathology department, Jinnah Hospital, Lahore, Pakistan, for biochemical and serological tests. This analytical study was carried out from March 2007 to September 2009 with collaboration of National Centre of Excellence in Molecular Biology, University of the Punjab, Lahore, Pakistan. Blood samples $(10 \mathrm{~mL})$ were collected from each patient and tested for anti-HCV antibody by ELISA. Adult ( $\geq 18$ years) patients with positive serology and/or positive test for HCV alone and no evidence of liver failure were included in this study. Patients who were not keen to give informed consent, not able to make followup visits and not willing to undergo genetic testing and allow samples to be stored for future research were excluded from the study. Accordingly, thus, $3160 \mathrm{HCV}$ RNA positive patients from $4020 \mathrm{HCV}$ antibody (antiHCV)-positive persons were identified. Questioner (including their personal, lab tests and demographical information, possible transmission route of $\mathrm{HCV}$ infection, clinical, virological and biochemical data) was prepared for patients who came for HCV initial screening and further genotyping and viral load quantification. The routine liver function tests (LFTs), Hb level and direct bilirubin were estimated for each patient in the hospital laboratory. Informed consent was obtained from patients. The study was approved by the institutional ethical committee.

\section{$\mathrm{HCV}$ antibody and viral assays}

$\mathrm{HCV}$ detection and genotyping was performed at the Department of Pathology, Jinnah Hospital, Lahore, Pakistan. RNA was extracted from $140 \mu$ l of serum samples using QIAamp viral RNA extraction kit (Qiagen, USA) according to the manufacturer's protocol. cDNA was synthesized using Moloney murine leukemia virus $(\mathrm{MmLV})$ followed by PCR using primers derived from the 5'UTR non-coding region of HCV genome described by Chan et al. [24]. For HCV RNA quantification, Qiagen HCV RG RT-PCR assay was used. Quantification was carried out with $10 \mathrm{ul}$ of the extracted RNA on Rotor-gene Real-Time PCR machine (USA) using fluorescent probes to detect amplification after each replicating cycle as described by manufacturer protocol. The lower limit of detection for this assay is $1000 \mathrm{IU} / \mathrm{ml} \mathrm{HCV}$ and genotyping was carried out using Invader HCV genotyping assay (Third wave technology, USA). Briefly, 100 ng of the HCV RNA was reverse transcribed to cDNA using $200 \mathrm{U}$ of MmLV (Invitrogen, USA). From the amplified product, $2 \mu \mathrm{l}$ were taken and the genotyping assay was performed for 12 different $\mathrm{HCV}$ types.

\section{Statistical analysis}

Statistical analysis was performed using the statistical package for social studies (SPSS) version 16 for windows. Student t-test and Chi-square tests were applied to evaluate differences in proportions. $P$ value $<0.05$ was considered significant. Univariate analysis includes the variables age, sex, Hb level, bilirubin, ALT, AST, ALP and viral load. Age, sex and genotypes were taken as independent categorical factors. The normal values of ALT, ALP, AST and direct bilirubin level were $(\sim 5-40 \mathrm{IU} / \mathrm{mL}),(<120$ $\mathrm{IU} / \mathrm{mL}),(\sim 10-40 \mathrm{IU} / \mathrm{mL})$ and $(<0.4 \mathrm{mg} / \mathrm{dl})$ respectively. Multiple regression analysis was used to evaluate independent associations between HCV genotypes and individual demographic characteristics and biochemical values to identify variables association within different genotypes. Once we determined that differences exist among the means, post hoc range tests and pair-wise multiple comparisons were determined. Comparisons were made on unadjusted values fixed between-patients factors only. The relationship between serum markers and genotypes were analyzed by Spearman's correlation for non-parametric data and by the Pearson method for parametric data. To obtain cutoff values of serum markers for HCV genotypes, receiver operating characteristics (ROC) curves were drawn for serum markers by 
plotting sensitivity of the assays against false positivity (1-specificity [25]. Comparison of the area under the curve (AUC) was used to assess the overall diagnostic values of serum markers.

\section{Results}

\section{Prevalence of $\mathrm{HCV}$ infection}

Of the 4020 ELISA positive patients, 3160 (78.6\%) showed positive PCR while 860 (21.4\%) were negative for HCV. Out of 3160 patients with positive PCR, 1515 (48\%) were males while 1645 (52\%) were females. The median age of patients was 37 years (range 18-75). Age of the patients was taken as a continuous as well as a categorical variable. Patients were divided into two age groups i.e. $\leq 40$ years and $>40$ years. In age group $\leq 40$ years there were 2119 patient, while age group $>40$ years include 1041 patients.

\section{Genotype distribution among patients}

Based on weighted analysis of patients infected with $\mathrm{HCV}$, the most frequently detected genotype was 3 (80\%), with predominant subtype $3 \mathrm{a}(73.9 \%)$ and $3 \mathrm{~b}$ (6.1\%). Genotype 1 (10.7\%) was exclusively consisted of the subtype 1a, while genotype 4 (7.1\%) comprised the subtype a $(6.4 \%)$ and $b(0.7 \%)$. Patients with mix genotype $4 \& 5(0.8 \%)$ and untypable genotype $1(0.2 \%)$ were also identified. The genotype $2 \mathrm{~b}$ was detected in only three $(0.1 \%)$ patients. The frequency distribution of different genotypes according to age groups and gender is given in Table 1. Distribution of genotypes among age groups was not statistically different $(p=0.488)$. Genotype subtype $3 \mathrm{a}$ was the most prevalent genotype in both age groups followed by 1a. Only three patients $(0.14 \%)$ with genotype $2 \mathrm{~b}$ were observed in age group $\leq 40$ years. Overall prevalence of genotypes within gender was also statistically non-significant $(p=0.098)$.

\section{Association of age, gender and genotypes with serum markers and viral load}

Univariate analysis (Table 2 ) revealed that all serum markers were independently distributed between gender and age groups while serum markers including direct bilirubin level, serum ALP and ALT levels and viral load were significantly different among genotypes. Box plots of the above four significant serum markers with eight different HCV genotypes are shown in Figure 1. The overall mean bilirubin value was $0.74 \pm 0.18 \mathrm{mg} / \mathrm{dL}$. The bilirubin level was high in genotype $2 \mathrm{~b}(0.80 \pm 0.10), 4 \mathrm{a}(0.81 \pm 0.05), 4 \mathrm{~b}$ $(0.90 \pm 0.12), 4 \& 5(0.89 \pm 0.003)$ and untypable $(0.88 \pm$ $0.09)$ while genotype $1 \mathrm{a}(0.706 \pm 0.14)$ and $3 \mathrm{a}(0.735 \pm$ 0.20 ) showed a low bilirubin level. Serum ALP levels (mean $209.03 \pm 64 \mathrm{IU} / \mathrm{mL}$ ) were higher in genotype $1 \mathrm{a}(251 \pm 62.2), 2 \mathrm{~b}(287 \pm 36.37), 3 \mathrm{~b}(221.1 \pm 70.1), 4 \mathrm{a}$ (275.7 \pm 70.5$), 4 \mathrm{~b}(227.2 \pm 72.1), 4 \& 5(232.7 \pm 63.1)$ and untypable $(315.1 \pm 54.1)$ in comparison to genotype $3 \mathrm{a}$ (193.9 \pm 54.3$)$. Serum levels of ALT (mean value $71.1 \pm$ $35.06 \mathrm{IU} / \mathrm{mL})$ were significantly elevated in $2 \mathrm{~b}(105 \pm$ 9.64) and $4 \mathrm{a}(108.1 \pm 35.6)$ genotypes as compared to $1 \mathrm{a}$ (72.1 \pm 36.5$), 3 \mathrm{a}(67.6 \pm 32.9), 3 \mathrm{~b}(72.6 \pm 35.6), 4 \mathrm{~b}(75.6 \pm$ $31.3)$ and mix genotype $4 \& 5(74.4 \pm 37.02)$, while serum ALT levels were significantly low in patients with untypable genotype $(57.65 \pm 23.5)$. Viral load varied from $1.1 \times$ $10^{3} \mathrm{IU} / \mathrm{mL}$ to $8.5 \times 10^{8} \mathrm{IU} / \mathrm{mL}$ (mean, $6.8 \times 10^{7} \pm 1.2 \times$ $10^{8}$ ). The viral load was significantly higher in genotype $2 \mathrm{~b}$ $\left(1.5 \times 10^{7} \pm 2.3 \times 10^{7}\right)$ and $4 \mathrm{a}\left(2.1 \times 10^{7} \pm 1.1 \times 10^{7}\right)$ while the patients with genotype $1 \mathrm{a}\left(4.5 \times 10^{6} \pm 9.8 \times 10^{6}\right)$, 3a $\left(5.9 \times 10^{6} \pm 1.1 \times 10^{7}\right), 3 \mathrm{~b}\left(7.1 \times 10^{6} \pm 1.1 \times 10^{7}\right), 4 \mathrm{~b}(1.9$ $\left.\times 10^{6} \pm 3.1 \times 10^{6}\right), 4 \& 5\left(6.7 \times 10^{6} \pm 1.1 \times 10^{7}\right)$ and untypeable $\left(8.1 \times 10^{6} \pm 1.1 \times 10^{7}\right)$ showed intermediate viremia levels. Genotype 2b, 4b, mix and untypable were eliminated from further analysis because of small sample size. Further Multivariate analysis in Table 3 revealed that

Table 1 Genotype-specific representation according to gender and age

\begin{tabular}{|c|c|c|c|c|c|c|c|c|}
\hline \multirow{3}{*}{ Characteristics } & \multicolumn{8}{|c|}{ Genotypes } \\
\hline & \multirow{2}{*}{$\begin{array}{c}1 \\
1 \mathrm{a}\end{array}$} & \multirow{2}{*}{$\frac{2}{2 b}$} & \multicolumn{2}{|c|}{3} & \multicolumn{2}{|c|}{4} & \multirow{2}{*}{$\begin{array}{l}\text { Mix } \\
4 \& 5\end{array}$} & \multirow{2}{*}{$\begin{array}{c}\text { Untypable } \\
\text { N.T }\end{array}$} \\
\hline & & & $3 a$ & $3 b$ & $4 a$ & $4 b$ & & \\
\hline Total $(n=3160)$ & $\begin{array}{c}339 \\
(10.7 \%)\end{array}$ & $\begin{array}{c}3 \\
(0.09 \%)\end{array}$ & $\begin{array}{c}2336 \\
(73.9 \%)\end{array}$ & $\begin{array}{c}194 \\
(6.1 \%)\end{array}$ & $\begin{array}{c}202 \\
(6.4 \%)\end{array}$ & $\begin{array}{c}22 \\
(0.69 \%)\end{array}$ & $\begin{array}{c}26 \\
(0.82 \%)\end{array}$ & $\begin{array}{c}38 \\
(1.2 \%)\end{array}$ \\
\hline Mean Age (SD) & $\begin{array}{c}36.3 \\
(9.63)\end{array}$ & $\begin{array}{c}36.67 \\
(2.8)\end{array}$ & $\begin{array}{c}37.39 \\
(10.42)\end{array}$ & $\begin{array}{c}36.19 \\
(10.62)\end{array}$ & $\begin{array}{c}37.01 \\
(10.24)\end{array}$ & $\begin{array}{c}32.45 \\
(9.5)\end{array}$ & $\begin{array}{c}33.46 \\
(9.7)\end{array}$ & $\begin{array}{c}35.42 \\
(9.7)\end{array}$ \\
\hline Age Range (years) & $18-66$ & $35-40$ & $18-75$ & $18-74$ & $18-70$ & $18-55$ & $18-51$ & $18-50$ \\
\hline \multicolumn{9}{|l|}{ Age Groups (years) } \\
\hline$\leq 40(n=2119)$ & 242 & 3 & 1534 & 140 & 136 & 18 & 21 & 25 \\
\hline$\geq 40(n=1041)$ & 97 & 0 & 802 & 54 & 66 & 4 & 5 & 13 \\
\hline \multicolumn{9}{|l|}{ Sex } \\
\hline Male $(n=1515)$ & 152 & 0 & 1117 & 111 & 95 & 11 & 9 & 20 \\
\hline Female $(n=1645)$ & 187 & 3 & 1219 & 83 & 107 & 11 & 17 & 18 \\
\hline
\end{tabular}


Table 2 Univariate analysis of patient's data by age, sex and genotype

\begin{tabular}{|c|c|c|c|c|c|}
\hline \multirow[t]{2}{*}{$\begin{array}{l}\text { Factors } \\
\text { Studied }\end{array}$} & \multirow[t]{2}{*}{$\begin{array}{l}\text { Serum } \\
\text { Markers }\end{array}$} & \multicolumn{2}{|c|}{$\begin{array}{l}\text { 95\% Confidence } \\
\text { Interval }\end{array}$} & \multirow[t]{2}{*}{ F-value } & \multirow[t]{2}{*}{$p$-value } \\
\hline & & $\begin{array}{l}\text { Lower } \\
\text { Bound }\end{array}$ & $\begin{array}{l}\text { Upper } \\
\text { Bound }\end{array}$ & & \\
\hline \multirow[t]{6}{*}{ AGE } & $\mathrm{Hb}$ level & 12.800 & 12.986 & 1.759 & .134 \\
\hline & $\begin{array}{l}\text { Bilirubin } \\
\text { level }\end{array}$ & .735 & .753 & .308 & .873 \\
\hline & ALP & 204.201 & 210.449 & 1.007 & .402 \\
\hline & ALT & 68.395 & 71.810 & 1.056 & .377 \\
\hline & AST & 66.299 & 69.655 & 1.017 & .397 \\
\hline & Viral load & 6409.094 & 7578.840 & .698 & .593 \\
\hline \multirow[t]{6}{*}{ GENDER } & Hb level & 12.783 & 12.916 & 2.537 & .111 \\
\hline & $\begin{array}{l}\text { Bilirubin } \\
\text { level }\end{array}$ & .739 & .752 & .164 & .686 \\
\hline & ALP & 206.795 & 211.275 & .004 & .952 \\
\hline & ALT & 69.798 & 72.246 & 2.380 & .123 \\
\hline & AST & 66.695 & 69.101 & .730 & .393 \\
\hline & Viral load & 6425.361 & 7263.954 & .021 & .886 \\
\hline \multirow[t]{6}{*}{ GENOTYPE } & Hb level & 12.361 & 12.996 & 1.295 & .248 \\
\hline & $\begin{array}{l}\text { Bilirubin } \\
\text { level }\end{array}$ & .787 & .847 & 17.846 & .000 \\
\hline & ALP & 240.926 & 260.033 & 108.589 & .000 \\
\hline & ALT & 73.576 & 84.729 & 39.728 & .000 \\
\hline & AST & 63.472 & 74.892 & 1.070 & .380 \\
\hline & Viral load & 6944.945 & 10731.895 & 48.110 & .000 \\
\hline
\end{tabular}

bilirubin, ALP, ALT levels and viral load were significantly different among genotypes 1a, 3a, 3b and 4a.

\section{Correlation of Significant Serum Markers and Viral load within HCV genotypes}

A correlation of significant serum markers with each other and viral load in HCV infected patients is illustrated in Figure 2 showed that viral load has positive correlation with ALP in genotype 1 a $(r=0.118, p=$ $0.030)$, linear significant correlation of viral load and AST was found in $3 \mathrm{~b}(r=-0.157, p=0.029)$, while negative linear correlation of $\mathrm{Hb}$ level with viral load in genotype $4 \mathrm{a}$, was observed $(r=-0.169, p=0.016)$. Regarding relationship between clinical factors, we observed significant correlations between ALP and ALT $(r=-0.214, p=0.000)$ in genotype 1a (Figure 3), ALT and AST $(r=0.042, p=0.043)$ and ALP and ALT $(r=$ -0.046, $p=0.027)$ in genotype 3a, and AST and ALP $(r=-0.175, p=0.013)$ in genotype $4 \mathrm{a}$.

\section{Determination of cutoff values of serum markers to predict genotypes}

ROC curves (Figure 4) to predict genotypes among patients were plotted against serum markers and we were able to found best cutoff points for genotype 4a. The best cutoff values calculated to predict genotype $4 \mathrm{a}$ were as: $\mathrm{Hb}$ level $\leq 11.85 \mathrm{~g} / \mathrm{dL}$, bilirubin level $\geq 0.75$ $\mathrm{mg} / \mathrm{dL}$, ALP level $\geq 243 \mathrm{IU} / \mathrm{mL}, \mathrm{ALT} \geq 125 \mathrm{IU} / \mathrm{mL}$, AST level $\sim 40-75 \mathrm{IU} / \mathrm{mL}$ and serum viral load $\geq 1 \times$ $10^{7} \mathrm{IU} / \mathrm{mL}$. The cut off values with significant positive predictive values (PPV) and negative predictive values (NPV) and specificity and sensitivity for genotypes 4a are given in Table 4. ALT, ALP, viral load and bilirubin levels showed high PPV and NPV as compared to AST and $\mathrm{Hb}$ level. Moreover, during evaluation the area under the curve (AUC) of each serum marker as illustrated in Table 5 we observed high AUC for ALP 0.763 (95\% Cl 0.724-0.801, $p=0.000)$, ALT $0.790(95 \% \mathrm{Cl}$ $0.756-0.824, p=0.000)$ and viral load $0.872(95 \% \mathrm{Cl}$ $0.854-0.890, p=0.000)$ while bilirubin level $0.664(95 \%$ $\mathrm{Cl} 0.641-0.0 .686, p=0.000)$, AST 0.454 (95\% Cl 0.414$0.494, p=0.028)$ and $\mathrm{Hb}$ level $0.458(95 \% \mathrm{Cl} 0.418$ $0.497, p=0.045)$ showed moderate AUC.

\section{Discussion}

The difference in distribution of HCV genotypes suggests the subsistence of diverse form of disease acquirement. The basic aim of this study was to evaluate the predictive value of a combination of basic serum biochemical markers for the diagnosis of genotypes and their relation to disease outcome.

The present study was conducted in randomly selected samples of general population in Pakistan (Table 1). Our patient's data showed no significant differences in genotype distribution in relation to gender and age groups. Various genotypes, particularly 1, 3 and 4 were equally distributed in gender and age groups. Prevalence of genotype in our study was: genotype 3 (n $=2530,80 \%)$, followed by genotype $1(\mathrm{n}=339,10.8 \%)$ and genotype $4(\mathrm{n}=224,7.08 \%)$. Subtypes $3 \mathrm{a}, 1 \mathrm{a}$ and $4 \mathrm{a}$ were predominant, whereas mix subtype $4 \mathrm{a} / 5 \mathrm{a}$ was also found in some patients $(\mathrm{n}=26,0.8 \%)$. Among patients, $1.2 \%(\mathrm{n}=38)$ showed untypable genotype.

The correlation among HCV genotypes with viral load and serum markers and their association with disease severity and sensitivity to interferon treatment remains controversial till date $[26,27]$. Evaluating the correlation between different clinical markers with genotypes, our results showed that a combination of four clinical markers (ALT, AST, ALP and bilirubin level) and serum viral load can have high positive or negative predictive value for diagnosis of different HCV genotypes. Our data showed significant increase in bilirubin levels in patients with genotypes 4 , mix (4\&5) and untypable. High bilirubin level is usually associated with liver metastases and liver tumor involvement leading to hepatocellular carcinoma and liver cirrhosis by active or nonactive HCV or HBV [28]. As different genotypes lead to diverse severity levels of liver disease so the treatment plan of chronic HCV infection with interferon varies 


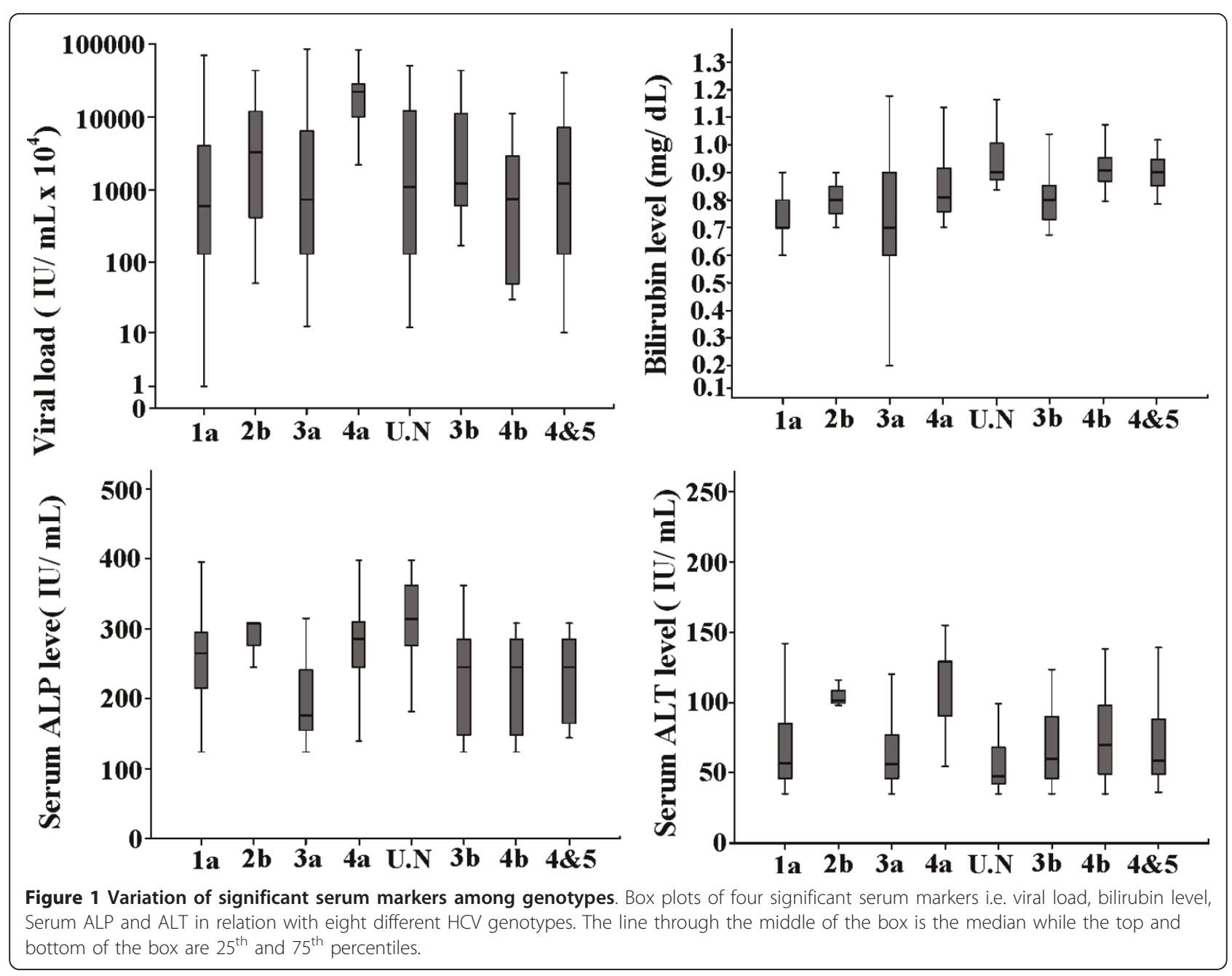

Table 3 Multivariate analysis of significant serum markers among genotypes $1 \mathrm{a}, 3 \mathrm{a}, \mathbf{3 b}$ and $4 \mathrm{a}$

\begin{tabular}{cccccc}
\hline $\begin{array}{c}\text { Serum } \\
\text { Markers }\end{array}$ & Genotypes & \multicolumn{2}{c}{$\begin{array}{c}95 \% \text { Confidence } \\
\text { Interval }\end{array}$} & \multicolumn{2}{c}{ Hypothesis Test } \\
\cline { 2 - 6 } & & Lower & Upper & $\begin{array}{c}\text { Wald Chi- } \\
\text { Square }\end{array}$ & Sig. \\
\hline $\begin{array}{c}\text { Bilirubin } \\
\text { level }\end{array}$ & $1 \mathrm{a}$ & -.262 & -.117 & 26.314 & 0.000 \\
& 3a & -.231 & -.091 & 20.225 & 0.000 \\
& 4a & -.250 & -.099 & 20.463 & 0.000 \\
ALP & 1a & 17.962 & 18.760 & 8140.621 & 0.000 \\
& 3a & -61.075 & -16.561 & 11.685 & 0.001 \\
& Aa & 42.554 & 43.371 & 42517.226 & 0.000 \\
& $1 \mathrm{a}$ & -2.660 & -1.862 & 123.417 & 0.000 \\
& 3a & -7.100 & -6.327 & 1159.056 & 0.000 \\
Viral load & 4a & 33.247 & 34.063 & 26090.882 & 0.000 \\
& 1a & -2221.812 & -2221.014 & $1.192 \mathrm{E} 8$ & 0.000 \\
& 3a & -771.541 & -770.768 & $1.529 \mathrm{E} 7$ & 0.000 \\
& 3b & 454.651 & 455.470 & $4.747 \mathrm{E} 6$ & 0.000 \\
& 4a & 14092.652 & 14093.469 & $4.575 \mathrm{E} 9$ & 0.000 \\
\hline
\end{tabular}

with the genotype being treated [29]. Bilirubin may be used as marker of liver injury and to determine the proper dose of interferon in patients with different genotypes. Elevated aminotransferases levels act as indicators of liver cell injury and are usually predominant in liver cirrhosis with increased ALT levels $[20,30]$. We observed elevated ALT and AST levels in all genotypes compared to normal range but in patients infected with genotype $4 \mathrm{a}$ values were quite higher $(>2$ times to normal range 5-40 $\mathrm{IU} / \mathrm{mL}$ ). These results could lead to the confirmation association of genotype 4a with increased risk of cirrhosis [31]. In previous studies, serum ALP levels were not considered valuable markers during $\mathrm{HCV}$ diagnosis but recent studies revealed that the higher levels of ALP are usually associated with liver metastasis, extraheptic bile obstruction, primary biliary cirrhosis, intraheptic cholestasis, infiltrative liver disease, hepatitis, cirrhosis, primary sclerosisng cholangitis, hepatic lymphoma, liver abscess, sarcoidosis and congestive cardiac failure [31-33]. A change in ALP levels greater 

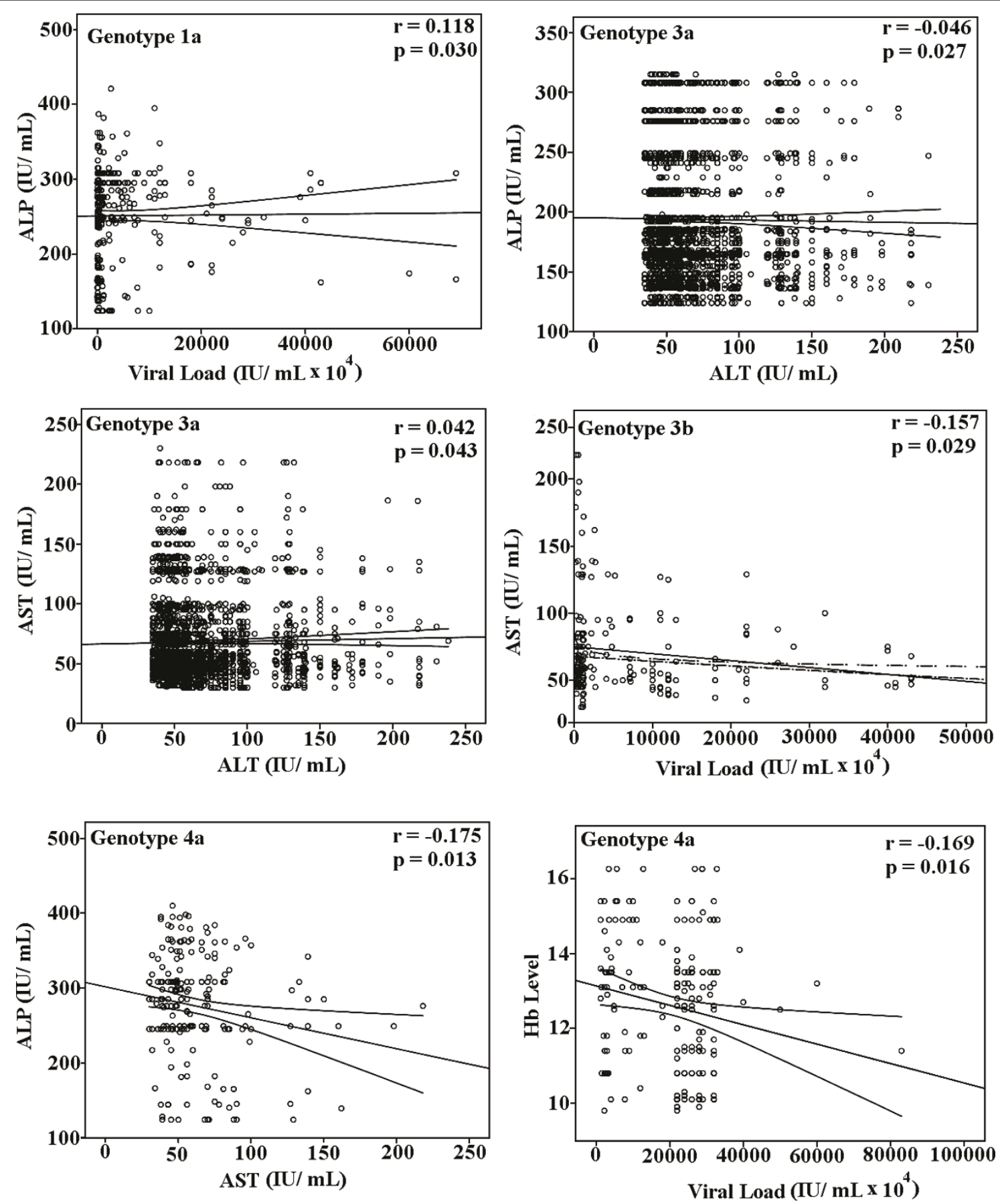

Figure 2 Correlation of serum markers with each other in HCV genotypes. Significant correlation between different serum markers in genotypes 1a, 3a, 3b and 4a was found. This can lead to different possible mechanisms of liver injury in different genotypes.

than $120 \mathrm{U} / \mathrm{L}$ can be indicative of advanced disease progression [34]. In our study patients with genotype 4a reflected high ALP levels as compared to others as illustrated in Figure 1.

Patients infected with genotype 3a showed negative correlation between ALP and ALT while a positive correlation was also found between AST and ALT in patients infected with genotype $3 \mathrm{a}$. No correlation between serum viremia levels and other serum markers in genotype $3 \mathrm{a}$ in our study was in agreement with outcome of Azzari et al and Abraham et al that the viral load was independent of ALT activity in $\operatorname{HCV}[18,35]$. 


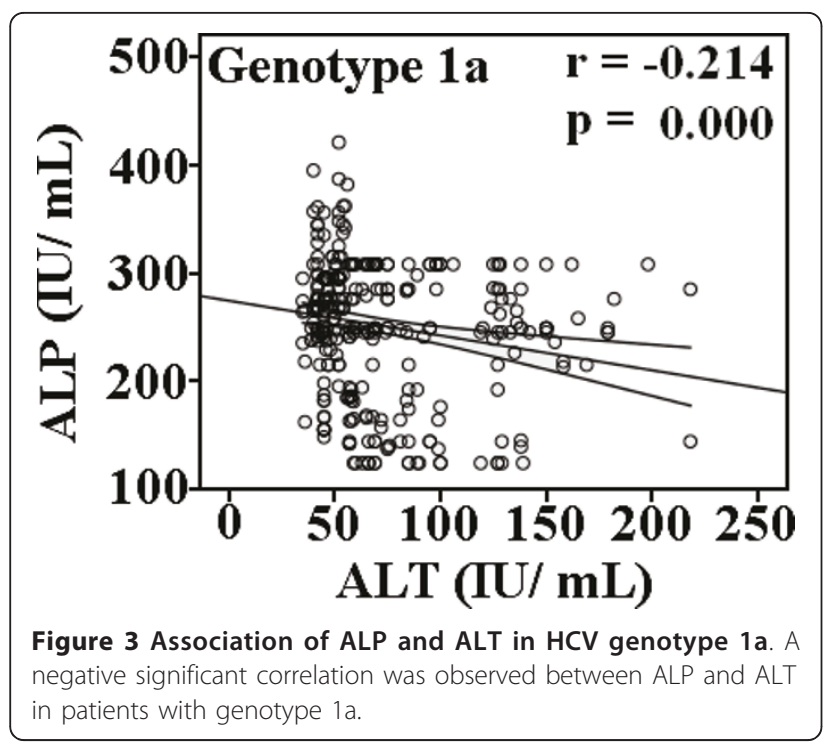

A linear relationship established between serum $\mathrm{HCV}$ RNA levels and amount of virus in liver or serum HCV RNA levels and liver injury and vice versa in many studies. The involvement of different factors like different clinico-histopathological evaluation procedures $[2,16]$ can lead to the opinion that liver injury in HCV infection due to genotype $3 \mathrm{a}$ is not directly associated with serum viremia levels or the number of infected hepatocytes. Zechini et al found a relation between HCV viral load and AST. However, we observed a negative correlation between viral load and AST in genotype $3 \mathrm{~b}$ that

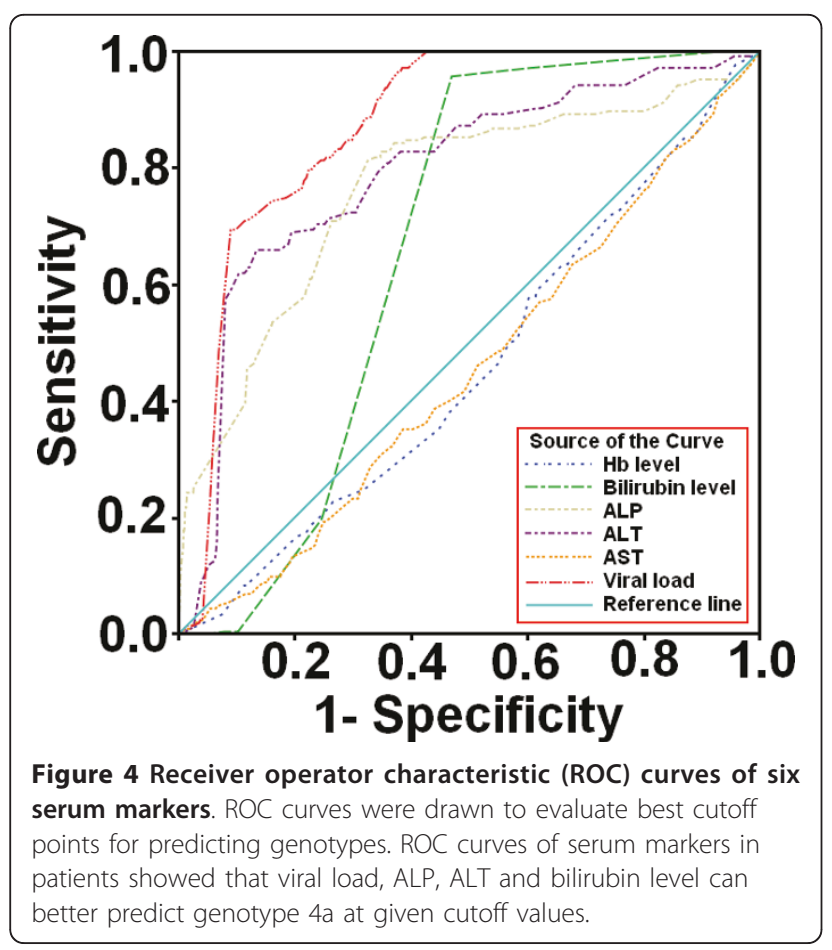

Table 4 Sensitivity, specificity, and cutoff values of the six serum markers to predict genotype $4 a$

\begin{tabular}{cccccc}
\hline $\begin{array}{c}\text { SERUM } \\
\text { MARKERS }\end{array}$ & Cutoff values & Sensitivity & Specificity & $\begin{array}{c}\text { PPV } \\
\text { (\%) }\end{array}$ & $\begin{array}{c}\text { NPV } \\
\text { (\%) }\end{array}$ \\
\hline $\begin{array}{c}\text { Hb level } \\
\begin{array}{c}\text { Bilirubin } \\
\text { level }\end{array}\end{array}$ & $11.85 \mathrm{~g} / \mathrm{dL}$ & 60 & 37 & 65 & 44 \\
ALP & $243 \mathrm{mg} / \mathrm{dL}$ & 96 & 53 & 96 & 60 \\
ALT & $125 \mathrm{IU} / \mathrm{mL}$ & 81 & 62 & 82 & 78 \\
AST & $\sim 40-75 \mathrm{IU} / \mathrm{mL}$ & 51 & 45 & 62 & 96 \\
Viral load & $1 \times 10^{7} \mathrm{IU} / \mathrm{mL}$ & 75 & 82 & 77 & 86 \\
\hline
\end{tabular}

may be due to poor immune response resulting in lower AST level and higher viral load and vise versa lead to liver damage $[19,36]$.

In patients infected due to genotype $1 \mathrm{a}$, viral load showed significant positive correlation with ALP, and ALP with ALT. Serum ALT and ALP can be used for assessing the liver function status in anti-HCV positive patients [37]. As elevated levels of ALP, ALT and AST are associated with liver injury leading to cirrhosis, $\mathrm{HCV}$ infection with genotype 1a could lead to more severe liver damage as compared to genotype 3.

In our study patients infected with genotype $4 \mathrm{a}$ showed high serum viral loads as compared to others, while an inverse correlation between viral load and $\mathrm{Hb}$ level and serum AST and ALP levels in genotype 4a was also observed. Kato et al monitored significantly higher HCV RNA level in patients with chronic active hepatitis and cirrhosis compared to chronic persistent hepatitis [38]. As HCV is associated with many extra hepatic complications involving renal, articular, neuorologic, cutaneous and haemopoietic systems, several autoimmune phenomenon are observed in patients infected with $\mathrm{HCV}[39,40]$, decline of $\mathrm{Hb}$ level with increase of viral load in genotype 4 may lead to autoimmune haemolytic anemia (AIHA) that can contribute to enhance the liver cirrhosis in genotype 4 as the patients with $\mathrm{HCV}$ related AIHA have higher prevalence of cirrhosis

Table 5 AUROC analysis of serum markers for predicting genotype $4 \mathrm{a}$ in chronic HCV patients

\begin{tabular}{cccccc}
\hline $\begin{array}{c}\text { Serum } \\
\text { Marker }\end{array}$ & Area & $\begin{array}{c}\text { Std. } \\
\text { Error }\end{array}$ & Significance & \multicolumn{2}{c}{$\begin{array}{c}95 \% \text { Confidence } \\
\text { Interval }\end{array}$} \\
\cline { 3 - 6 } & & & & $\begin{array}{c}\text { Lower } \\
\text { Bound }\end{array}$ & $\begin{array}{c}\text { Upper } \\
\text { Bound }\end{array}$ \\
\hline Hb level & 0.458 & 0.020 & 0.045 & 0.418 & 0.497 \\
$\begin{array}{c}\text { Bilirubin } \\
\text { level }\end{array}$ & 0.664 & 0.011 & 0.000 & 0.641 & 0.686 \\
ALP & 0.763 & 0.020 & 0.000 & 0.724 & 0.801 \\
ALT & 0.790 & 0.017 & 0.000 & 0.756 & 0.824 \\
AST & 0.454 & 0.020 & 0.028 & 0.414 & 0.494 \\
Viral load & 0.872 & 0.009 & 0.000 & 0.854 & 0.890 \\
\hline
\end{tabular}


[41]. Higher ALP and bilirubin levels and mild increase in AST levels in patients with genotype 4a may lead to cholestatic hepatitis that is a severe form of HCV recurrence after treatment and organ transplantation like liver, kidney and heart $[42,43]$.

Based on our findings, we calculated the optimum cutoff values of serum markers by generating ROC curves to predict $\mathrm{HCV}$ genotypes in HCV-RNA positive patients. To assess the diagnostic accuracy of serum markers to evaluate patients require the selection of a decision threshold. As, both sensitivity and specificity are equally important in classifying patients with positive PCR for genotypes, we were able to find the best cutoff values of each serum marker for genotype $4 \mathrm{a}$ that can maximize the sum of sensitivity and specificity as illustrated in Table 4. At given cutoff values for each serum marker in patients infected with genotype $4 \mathrm{a}, 60 \%$ have raised ALT $\geq 125 \mathrm{IU} / \mathrm{mL}, 82.5 \%$ have elevated ALP $\geq 243 \mathrm{IU} / \mathrm{mL}$, 99.5\% have bilirubin level more than $\geq 0.8 \mathrm{mg} / \mathrm{dL}$ and $95 \%$ with raised serum viremia levels up to $\geq 1 \times 10^{7} \mathrm{IU} /$ $\mathrm{mL}, 75.2 \%$ have low Hb level $(\leq 11.85 \mathrm{~g} / \mathrm{dL})$ and $65 \%$ showed mild increase in AST levels $(40 \sim 75 \mathrm{IU} / \mathrm{mL})$. The percentage accuracy of each serum marker at given cutoff values is; Hb level 58\%, bilirubin level 73.2\%, ALP 70.3\%, ALT $86.5 \%$, AST $44.6 \%$ and viral load $84.6 \%$. These all serum markers in combination may predict genotype $4 \mathrm{a}$ in patients with more than $75 \%$ accuracy.

In Pakistan due to poverty, doctors usually do not recommend the genotype testing, as they consider $\mathrm{HCV}$ 3a more prevalent and INF therapy responder, but due to high frequency of genotype 1a and $4 \mathrm{a}$ and for better dose administration, time course of INF therapy and sustainable response, importance of genotyping cannot be neglected. It is conceivable that serum viral load, ALT, ALP and bilirubin levels are suitable factors that may determine liver damage as well as HCV genotypes. Although all genotypes showed significant variable response to the serum markers, we were able to find serum markers with viral load that can predict genotype $4 \mathrm{a}$, with more than $75 \%$ accuracy. However we recommend genotyping assay to find possible association with disease severity and guide about treatment duration and outcomes. Future studies are required in liver biopsy samples to confirm the association we found in this study.

\section{Abbreviations \\ HCV: hepatitis C; PPV: positive predicted value; NPV: negative predicted value; AUC: area under the curve; ROC: receiver operating characteristic}

\section{Acknowledgements}

The authors wish to thank all laboratory staff for their help in gathering data.

\section{Author details}

${ }^{1}$ Applied and Functional Genomics Lab, Centre of Excellence in Molecular Biology, University of the Punjab, Lahore-53700, Pakistan. Fouzia Tahir Javed, Department of Pathology, Jinnah Hospital, Lahore-54590, Pakistan.

\section{Authors' contributions}

WA and $\mathrm{BI}$ contributed equally to this study. WA, BI and $\mathrm{SH}$ designed the study, analyze the data and wrote paper. AS, HK, SG, Sarwar MT and IS performed all lab work. FTJ and SA collected and arranged data. All work was performed under supervision of SH. All the authors read and approved final version of manuscript.

\section{Competing interests}

The authors declare that they have no competing interests.

Received: 1 April 2011 Accepted: 10 June 2011 Published: 10 June 2011

\section{References}

1. Alter MJ: Epidemiology of hepatitis C. Hepatology 1997, 26:62S-65S.

2. Giannini C, Bréchot C: Hepatitis C virus biology. Cell Death Differ 2002, 10: S27-38.

3. Abid K, Quadri R, Veuthey AL, Hadengue A, Negro F: A novel hepatitis C virus (HCV) subtypes from Somalia and its classification into HCV Clade 3. J Gen Virol 2000, 81:1485-1493.

4. Candotti DJ, Temple J, Sakodie F, Allain JP: Frequent recovery and broad genotype 2 diversity characterize hepatitis $C$ virus infection in Ghana, West Africa. J Virol 2003, 77(14):7914-7923.

5. Ndjomou J, Pybus OG, Matz B: Phylogenetic analysis of hepatitis C virus isolates indicates a unique pattern of endemic infection in Cameroon. $J$ Gen Virol 2003, 84(9):2333-2341.

6. Simmonds P: Genetic diversity and evolution of hepatitis C virus-15 years on. J Gen Virol 2004, 85(11):3173-3188.

7. Raja NS, Janjua KA: Epidemiology of hepatitis $C$ virus infection in Pakistan. J Microbiol Immunol Infect 2008, 41(1):4-8.

8. Kumar D, Farrell GC, Fung C, George J: Hepatitis C virus genotype 3 is cytopathic to Hepatocytes: Reversal of hepatic steatosis after sustained therapeutic response. Hepatology 2002, 36:1266-1272.

9. Manns MP, McHutchison JG, Gordon SC, Rustgi VK, Shiffman M, Reindollar R, Goodman ZD, Koury K, Ling M, Albrecht JK: Peginterferon alfa- $2 \mathrm{~b}$ plus ribavirin compared with interferon alfa- $2 \mathrm{~b}$ plus ribavirin for initial treatment of chronic hepatitis C: a randomised trial. Lancet 2001, 358:958-965.

10. Ahmad W, ljaz B, Javed FT, Jahan S, Shahid I, Khan FM, Hassan S: HCV genotype distribution and possible transmission risks in Lahore, Pakistan. World J Gastroenterol 2010, 16(34):4321-4328.

11. Hamid S, Umar M, Alam A, Siddiqui A, Qureshi H, Butt J: Pakistan Society of Gasteroenterology. PSG consensus statement on management of Hepatitis C virus infection-2003. J Pak Med AssoC 2003, 54(3):146-150.

12. Derbala MF, Al Kaabi SR, El Deweik NZ, Pasic F, Butt MT, Yakoob R, AlMarri A, Amer AM, Morad N, Bener A: Treatment of hepatitis C virus genotype 4 with peginterferon alfa-2a: impact of bilharziasis and fibrosis stage. World J Gasteroenterol 2006, 12(35):5692-5698.

13. Kabir A, Alavian SM, Keyvani H: Distribution of hepatitis $\mathrm{C}$ virus genotypes in patients infected by different sources and its correlation with clinical and virological parameters: a preliminary study. Comp Hepatol 2006, 5:4.

14. Tassopoulos NC, Papatheodoridis GV, Katsoulidou A, Delladetsima JK, Sypsa V, Touloumi G, Nikandros M, Hatzakis A: Factors associated with severity and disease progression in chronic hepatitis $C$. Hepatogastroenterology 1998, 45(23):1678-1683.

15. Adinolfi LE, Gambardella M, Andreana A, Tripodi MF, Utili R, Ruggiero G: Steatosis accelerates the progression of liver damage of chronic hepatitis C patients and correlates with specific HCV genotype and visceral obesity. Hepatology 2001, 33(6):1358-1364.

16. El-Serag HB: Hepatocellular carcinoma and hepatitis $\mathrm{C}$ in the United States. Hepatology 2002, 36:S74-S83.

17. Idrees $M$, Riazuddin S: Frequency distribution of hepatitis $C$ virus genotypes in different geographical regions of Pakistan and their possible routes of transmission. BMC Infect Dis 2008, 8:69.

18. Azzari C, Resti M, Moriondo M, Ferrari R, Lionetti P, Vierucci A: Vertical transmission of $\mathrm{HCV}$ is related to maternal peripheral blood mononucleat cell infection. Blood 2009, 96(6):2045-2048.

19. Delic D, Nesic Z, Prostran M, Maksic N, Cutovic M, Simonovic J, Svirtlih N: The relationship of serum aminotransferase levels to viral load and genotype in chronic hepatitis C. Jugoslov Med Biochem 2005, 24(4):247-252 
20. Imbert-Bismut F, Ratziu V, Pieroni L, Charlotte F, Benhamou Y, Poynard T: Biochemical markers of liver fibrosis in patients with hepatitis $C$ virus infection: a prospective study. Lancet 2001, 357:1069-1075.

21. Kowala-Piaskowska A, Mozer-Lisewska I, Figlerowicz M, Sluzewski W: Influence of the presence of HCV-RNA in peripheral blood mononuclear cells on the clinical course of chronic hepatitis $C$ in children. Eur J Epidemiol 2007, 22(5):343-348.

22. Pratt DS, Kaplan MM: Evaluation of abnormal liver-enzyme results in asymptmatic patients. N Eng J Med 2000, 342(17):1266-1271.

23. Silva RG Jr, Fakhouri R, Nascimento TV, Santos IM, Barbosa LM: Aspartate aminotransferase-to-Platelet ration index for fibrosis and cirrhosis prediction in chronic hepatitis C patients. Braz J Infect Dis 2008, 12(1):15-19.

24. Chan SW, McOmish F, Holmes EC, Dow B, Peutherer JF, Follett E, Yap PL, Simmonds P: Analysis of a new hepatitis $C$ virus type and its phylogenetic relationship to existing variants. J Gen Virol 1992, 94:3576-3582.

25. Zweig MH, Campbell G: Receiver-operating characteristic (ROC) plots: a fundamental evaluation tool in clinical medicine. Clin Chem 1993, 39:561-577.

26. Al-Khurri LE, Al-Khafaji KR, Al-Salihi SA, Alwaysi SAA, Al-Akayshi RJ: Serum HCV-RNA levels in patients with chronic hepatitis C: Correlation with histological features. Arab J Gastroenterol 2009, 10:10-13.

27. De Moliner L, Pontisso P, De Salvo GL, Cavalletto L, Chemello L, . Alberti A: Serum and liver HCV RNA levels in patients with chronic hepatitis C: correlation with clinical and histological features. Gut 1998, 42:856-860.

28. Raymond E, Boige V, Faivre S, Sanderink GJ, Rixe O, Vernillet L, Jacques C, Gatineau M, Ducreux M, Armand JP: Dosage adjustment and pharmacokinetic profile of Irinotecan in cancer patients with hepatic dysfunction. J Clin Oncol 2002, 20:4303-4312.

29. Ramos B, Nunez M, Toro C, Sheldon J, Garcia-Samaniego J, Rios P, Soriano V: Changes in distribution of hepatitis $C$ virus (HCV) genotypes over time in Spain according to HIV serostatus: Implications for HCV therapy in HCV/HIV-coinfected patients. J Infect 2007, 54:173-179.

30. Green RM, Flamm S: AGA technical review on the evaluation of liver chemistry tests. Gastroenterology 2002, 123(4):1367-1384

31. Bircher J: Oxford textbook of clinical hepatology. New York; Oxford university press; 2 1999, 503-521.

32. Lee GH, Benner D, Regidor DL, Kalatar-Zadeh K: Impact of kidney bone disease and its management on survival of patients on dialysis. J Ren Nutr 2007, 17(1):38-44.

33. Wiwanikit $V$ : High serum alkaline phosphatase levels, a study in 181 Thai adult hospitalized patients. BMC Fam Pract 2001, 2:2.

34. Saif MW, Alexander D, Wicox CM: Serum Alkaline Phosphatase Level as Prognostic Tool in Colorectal Cancer: A study of 105 patients. J Appl Res 2005, 5(1):88-95.

35. Abraham R, Ramakrishna B, Balekuduru A, Daniel HD, Abraham P, Eapen CE, Kurian G: Clinicopathological features and genotype distribution in patients with hepatitis C virus chronic liver disease. Ind J Gastroenterol 2009, 28(2):53-58.

36. Zechini B, Pasquazzi C, Aceti A: Correlation of serum aminotransferases with HCV RNA levels and histological findings in patients with chronic hepatitis $C$ : the role of serum aspartate transaminase in the evaluation of disease progression. Eur J Gasteroenterol Heptol 2004, 16(9):891-896.

37. Murakami S, Okubo K, Tsuji Y, Sakata H, Takahashi T, Kikuchi M, Hirayama R: Changes in liver enzymes after surgery in anti-hepatitis $C$ virus-positive patients. World J Surg 2004, 28:671-674.

38. Kato N, Yokosuka O, Hosoda K, Ito Y, Ohto M, Omata M: Quantification of hepatitis $C$ virus by competitive reverse transcription polymerase chain reaction: increase of the virus in advanced liver disease. Hepatology 1993, 18(1):16-20.

39. Gumber SC, Chopra S: Hepatitis C: a multifactorial disease. Review of extrahepatic manifestations. Ann Intern Med 1995, 123:615-620.

40. Wilson RA: Extrahepatic manifestations of chronic viral hepatitis. Am J Gastroenterol 1997, 92(8):3-17.

41. Chiao EY, Engels EA, Kramer JR, Pietz K, Henderson L, Giordano TP, Landgren O: Risk of immune thrombocytopenic purpura and autoimmune hemolytic anemia among 120908 US veterans with hepatitis C virus infection. Arch Intern Med 2009, 169(4):357-363.

42. Deshpande V, Burd E, Aardema KL, Ma CK, Moonka DK, Brown KA, Abouljoud MS, Nakhleh RE: High levels of hepatitis $C$ virus RNA in native livers correlate with the development of cholestatic hepatitis in liver allografts and a poor outcome. Liver Transp/ 2001, 7(2):118-124

43. Ong JP, Barnes DS, Younossi ZM, Gronlich T, Yen-Lieberman B, Goormastic M, Sheffieled C, Hoercher K, Starling R, Young J, Smedira N, McCarthy P: Outcome of de novo hepatitis $C$ virus infection in heart transplant recipients. Hepatology 1999, 30(5):1293-1298.

doi:10.1186/1743-422X-8-293

Cite this article as: Ahmad et al:: HCV genotype-specific correlation with serum markers: Higher predictability for genotype 4a. Virology Journal $20118: 293$

\section{Submit your next manuscript to BioMed Central and take full advantage of:}

- Convenient online submission

- Thorough peer review

- No space constraints or color figure charges

- Immediate publication on acceptance

- Inclusion in PubMed, CAS, Scopus and Google Scholar

- Research which is freely available for redistribution

Submit your manuscript at www.biomedcentral.com/submit 